DOI: $10.17805 /$ zpu.2018.1.6

\title{
Цинизм как способ существования глобалистской культуры
}

\author{
Т. А. ГОРЕЛОВА \\ МОСКОВСКИЙ ГУМАНИТАРНЫЙ УНИВЕРСИТЕТ
}

В статье рассматривается роль цинического мировоззрения в современной культуре, которая названа автором глобалистской (понятие, производное от «глобализм» в интерпретации А. А. Зиновьева). Особые черты этой культуры проявляются как отсутствие национального ядра; массовидный характер; «вирусный» способ распространения; стремление к разрушению системы традиционных ценностей. Ядром данной культуры становится циническое мировоззрение, которое, проникая во все сферы современной жизни, действует не только как мировоззрение, но и как способ существования человечества.

По П. Слотердайку, исторический путь цинизма можно представить в виде расширения ложных установок и стереотипов как в индивидуальном, так и в общественном сознании: Ложь $\rightarrow$ Заблуждение $\rightarrow$ Идеология $\rightarrow$ Цинизм. Последний предстает как следующая после идеологии стадия социокультурной эволюции, как мировоззрение постмодерна. Жизнь в больших городах и информатизация сознания способствуют тому, что природа цинизма становится вирусной, а сам он в силу такой природы - диффузным. В работе показано, что в духовной сфере цинизм становится подменой духовного развития во всех отраслях культуры.

Цинизм современной экономической ситуации заключается на общественном уровне в том, что государственная власть больше не обладает суверенитетом, а решения на самом деле принимаются глобальной сверхвластью; на уровне отдельного человека деньги, превратившись в самодовлеющую сущность, сделали каждого средством для своего бытия. Цинизм глобальной социальной ситуации в том, что современная сверхвласть это не класс воинов, получивших свои регалии за мужество и доблесть, не класс аристократов, обладающих «генетическим» статусом на основе родословной, не класс буржуа, создавших массовое производство, и даже не сообщество государственных мужей, радеющих о будущности своего народа, а горстка удачливых и не брезгующих никакими средствами глобальных финансовых спекулянтов.

Цинизм технологического мира заключается в обещании все большей свободы, но на самом деле человек остается рабом, но не другого человека, а техники. Цинизм глобальной политической ситуации заключается в создании системы глобального неоколониализма и использовании двойных стандартов: государство, присваивающее себе роль демократического наставника человечества, является безжалостным агрессором, расчищающим себе жизненное пространство за счет других стран, при этом государственный терроризм и терроризм против государства мотивируются друг другом. Информационная сфера, управляемая СМИ, создает «кровеносную» систему глобалистской культуры, в которую ныне закачивается уже не идеологическая, а циническая информационная “жидкость». Предельный цинизм глобального человечества - «делать худшее, зная лучшее»особенно ярко проявляется в экологической сфере: с одной стороны, осознана ограниченность земных ресурсов, но с другой - резко возрастает воздействие человеческой деятельности на природу, что обостряет борьбу за ресурсы и одновременно усиливает отрицательные экологические последствия такого воздействия.

Ключевые слова: цинизм; глобализм; глобалистская культура; идеология; индивидуальность; эволюция

\section{ВВЕАЕНИЕ}

Процесс глобализации, осознанный в 70-е годы XX в., в XXI в. все больше приобретает черты, позволившие выдающемуся российскому философу А. А. Зиновьеву обозначить их через термин «глобализм». Существуют объективные основания тенденции глобализации - рост народонаселения, его экономической, ком- 
муникативной и информационной связанности, которые позволяли в XIX - начале XX в. считать это явление фактором положительным, ведущим к росту человеческой солидарности и единству человечества. Напротив, глобализацию по принципам глобализма нельзя назвать положительным явлением, поскольку объединение происходит уже не естественным путем, а под давлением одной, технически более оснащенной, западной цивилизации. «Идея “глобального общества” есть лишь идеологически замаскированная установка западного мира, возглавляемого США, на покорение всей планеты и на установление своего господства над всем прочим человечеством» (Зиновьев, 2007: 500).

Политика глобализма - это, по существу, продолжение Западом колониальной стратегии, которая оказалась очень выгодной, и «с XVI до середины XX в. этот культурно-политический охват обеспечил европейским государствам североатлантического региона дискретное политическое господство почти по всему земному шару» (Бжезинский, 2012: 18). Колониальная система была разрушена в середине ХХ в. под прямым влиянием СССР. Новое глобальное господство, как и колониальная система, устанавливается «огнем и мечом», поэтому современным итогом глобализма становится не глобальное общество «всеединства» (как мечтали русские религиозные мыслители XIX в.), а глобальная неоколониальная система (Горелов, 2014), которая предполагает отход от демократии не только по отношению к зависимым странами, но и внутри развитых стран и ведет к глобальному усилению неравенства.

По аналогии с глобализмом и как продолжение идеи Зиновьева о реальных процессах глобализации рождающуюся ныне глобальную культуру следует назвать глобалистской в силу разных обстоятельств. Во-первых, глобалистская культура не имеет отечества. Несмотря на то что ее основой и прообразом является западная культура, последняя также отрывается от национальной традиции и размывается. Это отсутствие культурного корня порождает внутренний разлад глобального человека, который «в качестве вожделеющего существа формируется уже не национальной, а общемировой системой духовно-символического производства, но в качестве производящего субъекта его возможности по-прежнему ограничены местными национальными рамками» (Панарин, 2001: 96). Россия пережила это раздвоение сознания в 90-е годы XX в., когда обнищавшим россиянам по телевизору демонстрировали роскошные автомобили, дорогую косметику и прочие атрибуты продвинутого общества потребления. Глобалистская социокультурная модель воплощает «принудительный дух, господствующее вожделение эпохи» (там же: 112).

Второй особенностью глобалистской культуры является ее ярко выраженный массовидный характер. Об этом написано много, но в данном случае важны такие черты массовой культуры, как склонность к упрощению, социальная деструктивность, нацеленность на потребление. Три указанные тенденции свидетельствуют о вырождении культуры, поскольку она как духовное производство, напротив, должна усложняться (уменьшение культурного разнообразия уменьшает стабильность социума и нарушает отношения человека с природой); способствовать социальной солидарности (массовизация ведет к разрушению семьи, неформальных связей, способствует «вирусному» распространению информации); заботиться о будущем (гонка потребления истощает природные ресурсы и отнимает возмож- 
ность жизни у будущих поколений). В глобалистской культуре, как и в материнской западной, все смешивается, универсализуется, становится индифферентным, исчезают своеобразие и оригинальность, и это всеобщее упрощение уносит страсть, идеал и смысл, питающие культуру.

Третьей особенностью глобалистской культуры является способ ее воздействия. Традиционная культура воздействует на разум и чувство, в нее входят компоненты веры и эмоции, т. е. она требует личного участия и отношения. Глобалистская культура воздействует по принципу «заражения» и имеет вирусный или наркотический характер. Современную музыку, триллеры, сериалы не столько слушают и смотрят, сколько на них «подсаживаются» (этот термин очень закрепился, по крайней мере, в русском обиходе). Парадоксально, но высокотехнологичная и рациональная культура западной цивилизации на самом деле «заражает» общепланетарную культуру фрагментами своего духовного разложения.

На четвертую особенность глобалистской культуры указывал Ж. Бодрийяр. «Создание глобальной системы является результатом страшной зависти - зависти безразличной культуры с размытыми определениями по отношению к культуре с четкими определениями... зависти десакрализованного общества по отношению к культурам, сохранившим жертвенные формы» (Бодрийяр, 2016а: 162). Бессознательным следствием зависти становится разрушение чужих ценностей, когда своих не осталось. Подобные прецеденты уже были в истории, например, когда испанские завоеватели полностью разрушили культуру и систему ценностей индейцев, чья религиозность была более интенсивной (там же: 202).

Глобалистская массовая культура ведет себя подобно испанским завоевателям: претендуя на объединение человечества, проникая во все сферы жизни и подменяя как народную, так и элитарную культуру, она отнимает возможность духовного творчества у поколения, родившегося в ней. Это можно назвать культурньц тоталитаризмом. Не важно, кто этот молодой человек - представитель элиты, среднего класса или обитатель дна, получит ли он хорошее образование или будет зарабатывать копейки тяжелым трудом, - вязкая среда глобализма почти не дает шансов духовно творить себя и мир. «Глобальная культурно-идеологическая ценностная матрица» (Макаревич, Карпухин, 2016: 178) фактически задает ориентиры духовной жизни всего человечества: создаются центры производства и экспансии смыслов, ценностей, символов и стандартов (как правило, в западных странах), которые контролируют производство и трансляцию новостей, произведений массовой культуры, развивают кинематограф, Интернет, телевидение.

Культура в широком смысле слова есть отражение разумности Homo sapiens и его способности к преображению мира. Глобалистская культура как порождение разума также выполняет эти функции, но, поскольку современный «глобальный разум» нацелен не на духовное, а на материальное преобразование, его природа меняется, и он становится ииническим разумом (Слотердайк, 2009).

Цель данной статьи автор видит в том, чтобы показать, как цинизм, проникая во все сферы современной жизни, становится не только мировоззрением, но и способом существования человечества. Глобалистская культура выполняет функции производства цинических установок, а отдельный человек, находясь в такой атмосфере и под таким давлением, фактически обречен стать циником. 


\section{ЦИНИЗМ КАК МИРОВОЗЗРЕНИЕ}

В понимании $\mathrm{XX}$ в. «цинизм - наглое, бесстыдное поведение, проникнутое презрением к морали и культуре» (Словарь русского языка, 1952: 810). Циническому поведению сопутствует мировоззрение, которое отрицает такие мотивы поведения, как стыд, вина, совесть, сострадание, сочувствие как не соответствующие эгоистическому интересу индивида. Циническое мировоззрение включает моральный релятивизм, существенно усиливая его, так как цинизм не столько принимает предлагаемые обстоятельства, сколько сам задает установку на принижение системы ценностей. Аевальвируя всю сферу «высокого», «духовного», он заведомо упрощает интерпретации мотивов поведения как других людей, так и собственные.

Цинизм как мировоззрение рождается «в осевое время»- момент в истории человечества, когда в разных цивилизациях почти в одно и то же время «зажглись очаги разума» (К. Ясперс). Борьба рациональности с мифологическим мышлением привела к становлению индивидуальности через осознание человеком себя как существа познающего. Осознанное отношение к миру, духовная индивидуальность человека и... иинизм как система эгоцентрической переоценки иенностей фактически рождаются одновременно. Античность впервые соприкасается и осознает это явление как кинизм (которое позже римлянами будет названо цинизмом1) и видит киника как философа-практика, чудака-одиночку, моралиста-провокатора, т. е. яркую социальную фигуру, претендующую на самобытность.

В средневековой христианской культуре элементы цинизма просматриваются в таком явлении, как юродство, которое понимается как феномен «смеховой народной культуры» (Иихачев, Панченко, Понырко, 1984). Поведение юродивого выглядит вызывающе, но сам он циником не является. Он наг, бездомен, пищу находит на «гноище», не обременен социальными обязательствами и свободен настолько, что любому, даже сильным мира сего, может сказать то, что сочтет нужным. Его цинизм - яркая социальная обложка, чтобы привлечь внимание. В средневековом исламе сходную с юродивым духовную нишу занимает дервиш (по-персидски - нищий), или суфий (по-арабски). Ипостаси дервиша - монах, нищий, факир, лекарь, прорицатель. И хотя дервиши могут говорить, что думают, цинический эпатаж сглажен, и социум воспринимает их скорее как святых и аскетов, т. е. вполне уважаемых членов общества. Азен-буддизм, также получивший широкое распространение в Средние века, доводит общую установку буддизма об иллюзорности существования человека и мира до парадоксального предела, из которого следует, что все несчастья и трагедии мира лишь комедия и фарс, за что и получает общий ярлык «восточного цинизма» (Карелин, 1999: 167). Отсутствие божества и отказ от личности как в Божественном, так и в человеческом смысле, а также установка на бесстрастность в конечном счете ведут к презрению к миру, а свобода от всего становится «свободой во имя ничего».

Каждая из мировых религий и крупных цивилизаций создали свои формы цинизма - путь пройден до конца. Современный глобальный цинизм в основе рожден на Западе, но берет от всех понемногу: с дзен-буддизмом он совпадает в главной установке - «разбожествление» мира (К. Ясперс), от юродства берет крикливые формы, странствующий дервиш задает ему вектор распространения. Современные черты глобального цинизма - пустота, презрение, бесстыдство, ирония без смысла - зарождаются в позднефеодальное время и окончательно оформляются в ка- 
питалистическом обществе Европы XIX в. Цинизм перестает быть «философией плебеев», как в античности, и способом пробуждения человека, как в русском Средневековье, и находит себе почву не только в городской культуре низов, но и в придворной сфере. Происходит расширение социального пространства цинизма. Ава встречных потока - с самого низа, от деклассированных европейских «интеллектуалов», и с самого верха, от аристократии и государственных мужей, - объединяются в своем ироническом отношении к христианской этике как существующей только для глупцов. Цинизм теряет свой потенциал позитивной силы для ценностной перестройки общества. Вобравший в себя негативы всех эпох современный цинизм полностью отрывает человека и от мира, и от самого себя.

После эпохи Просвещения, рационально и трезво вскрывшей общественные пороки, в буржуазном обществе оба потока - снизу и сверху - полностью сливаются и порождают массовый тип циника, некий усредненный социальный характер. Это интегрированный в общество, но внутренне противящийся ему индивид. Его взгляды не похожи на ехидный и злобный лай античной «собаки», они вполне корректны и отражают коллективный реалистически скорректированный взгляд на вещи. Он анонимен, что открывает широкие возможности тихо и исподволь перестраивать и собственную, и общественную систему ценностей. И вот за два столетия этой «демократической» внутренней работы западное общество приходит к юридически и даже церковно регистрируемым однополым бракам, ювенальной юриспруденции и прочим нарушениям традиционной морали.

Современный цинизм, так же как в Античности, является «продуктом» городской «жизнедеятельности», но в другом смысле: мегаполис, СМИ и новые технические средства коммуникации резко снижают импульсы, заставляющие человека стремиться к формированию собственной личности. Его лишенный полета эгоизм порождает, по Слотердайку, «просвещенное ложное сознание». Оно отличается от наивного цинизма Античности тем, что «усвоило наставления просветителей, но не осуществило того, к чему они призывали» (Слотердайк, 2009: 33). Глубинной основой ложного мироощущения является то, что просвещенческая критика европейской культуры оказалась более наивной, чем сознание, которое она хотела разоблачить. Ее добропорядочная рациональность не смогла последовать за постмодернистским сознанием, совершившим поворот к хитроумному плюралистическому реализму, который «проявляется как универсальный диффрузный иинизм» (там же: 29 ; курсив мой. $-T . Г$.).

Современное циническое мировоззрение является духовным и социальным антиподом кинического прообраза. Оно отвращается от идей добродетели и блага, которые были основополагающими для античной культуры, культивируя идеи денег, власти и особой, нужной им информации как главных «добродетелей» современности. Современное общество утрачивает духовную связь с природой, ибо ныне человеческая жизнь протекает во «второй природе» (М. Шеллинг), а то, что было в самом человеке природного, утрачено или обезображено. Свободе духа и независимой социальной позиции кинического индивидуализма противопоставляются разочарование и хандра современного циника-индивидуалиста, а утрата дерзости и сарказма в его жизненной позиции свидетельствует об истощении внутренних духовных источников. Киническая идея труда как главной ценности, радостной и свободной деятельности в XX в. становится все более цинической, пока ло- 
зунг «Труд делает человека свободным» не был помещен над воротами Освенцима. Киническому отвращению к наслаждениям современное общество противопоставляет рекламу и порнографию, потому что контроль за глобальной массой осуществляется не только с помощью насилия, но и «мягкой силой» - через образы желаемого. «Цинизм легко вырастает из либерального сексуального бродяжничества, для которого все едино, все одно и то же» (Слотердайк, 2009: 248). Аишь в одном цинизм остается похожим на кинизм: как и прежде, он предстает не оторванным от жизни теоретическим знанием, а практической программой жизни не только для отдельного человека, как это было в Аревней Греции, но и для общества в целом.

История динамического развития цинического мировоззрения свидетельствует о наличии веских причин для его существования. Онтологический источник цинизма видится в глубинной природе человека, в дисбалансе его стремления к удовольствию и самосохранению, в неравновесности его взаимодействия с природой, из которой он хочет взять сейчас как можно больше, но в то же время и дальше жить за ее счет. «Культура есть и следствие, и причина этого дисбаланса, есть способ ограничить, канализировать - культивировать этот баланс, это травматическое начало, этот радикальный антагонизм, которой, как разорванной пуповиной, человек отделен от природы, от живого гомеостаза» (Жижек, 1999: 13; курсив источника. - Т. Г.). В современном капиталистическом обществе «быть» - это значит у кого-то что-то отнимать - еду, место, энергию, жизнь - не в буквальном, а в конкурентном смысле.

Гносеологический источник цинизма проявляется как склонность к расщепленному мировидению, заложенная в природе человека как существа разумного. «Человек расщеплен в глубине своей сущности. Как бы он ни мыслил себя, мысля, он противостоит самому себе и всему остальному» (Ясперс, 1994: 378). Эволюция западной рациональности в эпоху Просвещения приводит к «утрате наивности» (П. Слотердайк), а развитая способность к самопознанию способствует краху объективизма. Мифологическая связь с природой исчезает, и рождается «сухая мудрость», которая не допускает «ничего нового в подлунном мире, потому что кости бессмысленной игры брошены, великие мысли все уже помыслены, возможные открытия заранее конструированы, а люди нацелены на самосохранение посредством приспособления...» (Хоркхаймер, Адорно, 1997: 26). «Природной тяге» к расщеплению и субъективной позиции наблюдателя человек во все времена пытался противопоставить сознательно создаваемые духовные конструкции, способствующие единству как отдельного сознания, так и культуры в целом. Такими конструкциями были духовные отрасли культуры, эволюционно возникающие по мере изменения духа человека, - мистика, искусство, мифология, философия, мировые религии, наука. Зародившаяся в XIX в. и ставшая доминирующей отраслью культуры в XX в. идеология резко отличается от стремившихся к объективации духовных систем прошлого: в ней всегда присутствует частный интерес. Растекающаяся в глобализирующемся обществе идеология занимает все пространства, оставляемые прежде плодотворными отраслями духовной культуры, и превращается в цинизм как последнюю оболочку ускользающего духа человека. Если юродивый надевал циническую маску, чтобы отринуть материальные покровы, отягощающие его путь к Богу, то современный человек, напротив, надевает одежды цинизма, чтобы спрятаться от 
беспредельного страха перед вечностью, к которой не подобраться, и бесконечностью, в которую не проникнуть. Цинизм как крайняя форма пессимизма, таким образом, замещает оптимистическое мировоззрение познающего разума.

Существует и аксиологическая причина быстрого распространения цинического мировоззрения, которая ярче всего тестирует «здоровье» культуры. По определению Ж. Бодрийяра, современную стадию культуры можно назвать фрактальной, вирусной или стадией диффузии ценностей. «Строго говоря, здесь уже не следовало бы прибегать к самому понятию ценности, поскольку такое дробление... делает невозможным какое-либо исчисление и оценку. $<\ldots>>$ мы сталкиваемся с ситуацией, аналогичной той, что имеет место в физике микромира: провести расчеты в терминах прекрасного и безобразного, истинного и ложного, доброго или злого так же невозможно, как вычислить одновременно скорость частицы и ее положение в пространстве» (Бодрийяр, 2012: 10-11). Цинизм как система быстрой переоценки ценностей и их девальвации становится наиболее подходящим мировоззрением для такой эпохи.

Подготовительной стадией для эпохи цинизма был XX в. как эпоха идеологии. «Восстание масс» в XX в. стало базисом и движущей силой одновременно и идеологии, и особой, массовой, культуры, которые переплелись между собой. Идеология, будучи доминирующей отраслью культуры, фактически формирует культуру масс. Как правящая культура она видит частный интерес, который стоит за идеологическими универсалиями, осознает дистанцию, разделяющую идеологическую маску и действительность, может время от времени менять эти маски, но никогда от них не отказывается. Только пристальный взгляд различает, что каждая идеологическая универсалия ложна по-своему. Например, экономическая идея свободы утверждает, что ее основание лежит в возможности для трудящихся «свободно продавать свой труд», но именно в этом акте продажи продающий (трудящийся) теряет свою свободу. Свобода вообще очень тонкая материя. Когда человек не свободен, недостижимая свобода кажется идеалом, но когда она доступна в разных сферах, то становится злом. Ж. Бодрийяр даже предлагает различать два понятия: свободу как идеал и освобождение «всего и вся, которое быстро приводит к критической точке» (Бодрийяр, 2016а: 197). В пример он приводит ситуацию с представительной демократией, которая на низовом уровне - безусловное благо, а на уровне высшей власти становится разочарованием и злом (там же: 198). Именно это освобождение от всего становится не только причиной разрушения традиционных социальных скреп - брака, семьи, связи поколений и пр., но разрушает и социальную природу личности.

Исторический путь цинического мировоззрения можно представить в виде расширения ложных установок и стереотипов как в индивидуальном, так и в общественном сознании от слабых и случайных форм обмана к более сложным и устойчивым: Аожь $\rightarrow$ Заблуждение $\rightarrow$ Идеология $\rightarrow$ Цинизм (Слотердайк, 2009: 30). По Слотердайку, цинизм становится как бы следующей стадией эволюции идеологии, это мировоззрение эпохи постидеологии. Жизнь в больших городах и информатизация сознания способствуют тому, что природа цинизма становится вирусной, а сам он в силу такой природы - дuффузным: проникает во все сферы общественной жизнедеятельности и претендует быть мировоззрением одновременно и отдельного человека, и глобальной культуры в целом. 


\section{ЦИНИЧЕСКИЕ УСТАНОВКИ ГАОБААИСТСКОЙ КУАБТУРЫ}

Если понимать под культурой (в широком смысле слова) все специфически человеческое (в противоположность естественному, существующему независимо от человека), в ее структуре можно выделить несколько сфер: Әуховную, которую мы считаем главной, поскольку она определяет все остальные, являясь «лакмусовой бумажкой» состояния человека и общества; әкономическую, которая формирует материальную базу общества; технологическую, которая ответственна за безопасность и имеет лидирующее положение в современном мире; политическую, или сферу управления обществом; сочиальную, которая определяет структуру отношений между людьми; экологическую, которая проявляет современные тенденции взаимодействия человека с природой; сферу личности как особый мир современного человека.

Мы попытаемся показать, что в каждой из этих сфер цинизм не только нашел свое место, но стал доминирующей силой, определяющей ее возможности и облик.

Ауховная сфера. Ее составляют отрасли, эволюционно возникающие по мере изменения духа человека: мистика, искусство, мифология, философия, мировые религии, наука, идеология. Раз возникнув, они остаются в пространстве культуры, обретая новые очертания под влиянием следующих эпох. Следуя логике П. Слотердайка, каждая из этих отраслей в наше время имеет ощутимый привкус цинизма, который приобретает формы, присущие именно этой отрасли культуры.

Как было показано выше, идеология, ставшая доминирующей отраслью культуры в XX в., в XXI в. уступает место циническому мировоззрению. С приходом эпохи цинического разума человечество оказывается в постидеологическом мире в том смысле, что идеология больше не стремится хоть в малой степени выражать истину, она не претендует даже на то, чтобы ее воспринимали всерьез, и приобретает манипулятивный и инструментальный характер, поддерживаемый «внеидеологическим насилием и посулами наживы» (Жижек, 1999: 36). Технические достижения и средства массовой информации расширили зону действия идеологии до планетарных масштабов, поэтому она стимулировала создание глобалистской массовой культуры, которая не только идеологизирована, но и цинична. Цинизм проникает в глубины сознания массового человека, который, осознавая фальшь идеологических универсалий, не собирается от них отказываться и принимает правила новой глобальной игры. Аля поколения, родившегося в этой управляемой глобальной среде, цинизм становится «практичным взглядом на жизнь»; «трезвостью ума и рассуждений»; «способностью все оценивать»; «способом выживания, панцирем, который спасает (ведь защитные реакции характерны Аля всех живых существ)»; «единственным, что позволяет оставаться разумным среди толпы»; «отпетые циники - в глубине души самые ранимые люди»; «доверчивые, искренние и чувствительные люди, сталкиваясь с несправедливостью, лживостью, лицемерием, вынуждены создавать вокруг себя оборонительную стену цинизма» (Блог-платформа «Цинизм...» ... : Электронный ресурс). Такой циник, как «гражданин геополитического, идеологического или религиозного лофта (от англ. loft - чердак, верхний этаж. - T. Г.), запирается сам и изнутри навешивает замок собственной нечувствительности» (Глюксман, 2006: 193). Цинизм этого молодого блогера весьма практичен, чем похож на кинизм, но вывернут наизнанку. 
Идеология имеет дело с массами, подлаживается под их интересы и запросы и в то же время моделирует их мировоззрение теперь уже в масштабах всей планеты. Глобальное управление массой әффективнее, если действует специальная универсальная массовая система управления, а не элитарные, доступные немногим системы типа науки или философии. Таким системным мировоззрением и стал цинизм, который, с одной стороны, дает ощущение индивидуального интеллектуального превосходства, а с другой - полностью адаптирует такого одиночку к мacce.

Но главный удар цинический разум наносит не по идеологии, которая изначально была покрыта цинической коростой, а по религиозному сознанию, священное знание которого под влиянием Просвещения было «вынуждено ретироваться, отступая в границы истории, филологии и логики», чем «уничтожается притязание традиции на абсолютность» (Слотердайк, 2009: 62). В ситуации, которую герой Ф. М. Аостоевского определил как «если Бога нет, то все дозволено», цинизм находит плодородную почву для жизни. Аакуны разветвленной духовной системы, созданной христианством в западной культуре, заполнялись духом цинизма. Изощренный ум неверующего священника выражает цинизм элиты, а ироническая критика социального строя и религиозных догм со стороны интеллектуалов-просветителей, с одной стороны, выражает мировоззрение низов, а с другой стороны, становится как бы позицией над всеми, т. е. метацинизмом. В конечном счете оказалось, что атеизм Просвещения открывает более широкую дорогу цинизму, чем религиозное лицемерие.

Но и в самой религии есть щель для цинизма - между искренней верой и ритуалом: в ритуале происходит подмена и «вместо субъектов начинают верить сами вещи» (Жижек, 1999: 38). Так появляется обрядоверие: например, в тибетские молитвенные барабаны - пишете молитву, кладете в барабан, поворачиваете его, и он молится за вас; в плакальщиц, которые скорбят об умершем вместо родственников; в свечи, которые ставят для поминания, и т. п. Вот и получается, что проникновение цинизма в религии ведет к порождению их антиподов: первоначально направленное против фарисейства христианство в средневековой Европе становится пародией государства и в баснословных масштабах превращается в аппарат духовного принуждения; в XX в. в лоне ислама взращивается экстремизм и терроризм (под лозунгом «Аллах, акбар!»), а буддизм, проникая в другие культуры, распространяется по миру, воспитывая презрение к нему.

Философия подошла к цинической черте в эпоху Просвещения. Осознанная относительность метафизики приводит к тому, что познание, казавшееся истинным, можно сказать, становится самообманом. Метафизические альтернативы «оказываются неразрешимыми: детерминизм против индетерминизма; конечность против бесконечности; существование Бога против несуществования, идеализм против материализма <...> с логической необходимостью имеются две возможности, и все они обоснованы одинаково хорошо и одинаково плохо. Не нужно, не надлежит и не позволяется "делать выбор" - с того момента, как выяснено, что оба варианта - отражение структуры разума» (Слотердайк, 2009: 76). Истина относительна, это значит - ее либо нет, либо она недостижима. Гносеологический поиск становится уже не горизонтом, движение к которому оправданно, а пределом, стремление к которому бессмысленно. 
Основная социальная цель Просвещения - сделать возможным появление активно действующего субъекта, т. е. человека, обладающего собственной волей и автономным началом, - также оказалась невыполнимой, так как активность деятеля сталкивается с развитой системой власти. Просветители первоначально не видели здесь противоречия. Например, находим у И. Канта: «Рассуждайте сколько угодно и о чем угодно, только повинуйтесь!» и «Меньшая степень гражданской свободы открывает простор для развития всех способностей народного духа» (Кант, 1966: 29). По Канту, политические и социальные ограничения делают человека более свободным в духовной сфере.

Но реальность оказалась другой. Просвещение обещает человеку стать субъектом - властелином природы и хозяином своих чувств и разума, но путь его взросления преграждает система власти, которая этого созревания не хочет, и природа, ресурсы которой ограничены. «С того момента как сообществу интеллектуалов становится очевидно, что никакое Просвещение невозможно без использования властного ресурса господствующего класса, оно входит в противоречие с самим собой» (Петров, 2015: 16). Это внутреннее противоречие Просвещения становится ядром цинизма последующей метафизики и философии в целом. Безрассудная самонадеянность субъекта должна быть ограничена не только в политическом, но и в теоретическом плане. Поэтому знание, формируемое деятелями Просвещения, дает власти возможность усиливать свое господство, создавая возможность не столько действующего, сколько господствующего субъекта. Критикуя сложившиеся политические отношения и одновременно свободно пребывая в них, Просвещение фактически направляет критику против самого себя, т. е. превращается в «тотальный обман масс», поскольку «знание - сила» не в том смысле, как понимал Ф. Бэкон, а сила, позволяющая властвовать. Все последующее развитие западной культуры подтверждает, что движущей силой Просвещения оказывается не столько жажда познания, сколько жажда власти - над природой, другими людьми, целыми народами. В культуре, созданной Просвещением, как бы объективно заложены негативные эффекты, исходящие из зашифрованного в субъекте стремления к господству. Философия, с момента своего зарождения в осевое время выражавшая смыслы культуры, ее чаяния и устремления, после Просвещения, создав субъекта, противопоставляющего себя окружающему как объекту и стремящегося все подчинить собственному контролю, была обречена закончиться «циническим разочарованием».

Поскольку искусство - самая синтетическая отрасль культуры, произведения которой создаются в творческом акте соединения художника с объектом его познания, циническое мировоззрение затрагивает и его. "Судьба искусства, судьба современного мира - одно. Там и тут бездуховная сплоченность всего утилитарного, массового, управляемого вычисляющим рассудком, противополагается распыленности личного начала, еще не изменившего духу, но в одиночестве, в заблуждении своем - в заблуждении не только разума, а всего существа - уже теряющего пути к целостному его воплощению» (Вейдле, 2011: 400). Под "распыленностью личного начала» Вейдле понимал такое состояние, когда художник, познавая себя и выражая свой внутренний мир, «одновременно отдавал себя, ибо внутренний мир его принадлежал не только ему» (там же: 307). Современный художник в глубине индивидуальности остается творцом, а значит, по-прежнему призван отдавать се- 
бя. Но цинизм социума - системы воспитания, образования и социальных отношений - способствует тому, чтобы подавить открытость творца и заглушить желание «отдавать себя». «Борьба за сохранение (хотя бы и духовное) голого “я" мешает ему (художнику. $-T$. Г.) стать дичностью и раскрыться в творчестве» (там же: 303 ). Так возникает непреодолимый разлад между циническим самосохранением и творческой отдачей. Самоубийственность цинической ориентации художника «прежде всякой литературы меня интересует одно: я сам» (М. Арлан) (цит. по: там же) - в том, что копание в глубинах замкнутого и одновременно расщепленного эго не способствует открытию в себе божественного начала. Невозможность духовного синтеза и глубинного самовыражения толкает творческого человека к поиску чисто внешних форм проявления. Отсюда весь этот современный цинический эпатаж с перемещением персонажей классического театра в наше время, откровенной сексуальностью в театре и литературе и прочие «успехи» массового и поп-искусства. Все более глубокое проникновение цинической ориентации в современное искусство лишь усиливает эти тенденции.

Универсальность науки отводит ей особое место в глобалистской культуре. Целостность науки, опирающаяся на специфический язык, экспериментальный метод и внутреннюю логику развития, создается относительно замкнутым сообществом - учеными, представителями разных культур, чья страсть к познанию сильнее национальных отличий. Объединяющий потенциал научного знания делает науку одним из средств глобализации человечества. Но в универсальности науки скрыта и негативная сторона, которую И. Кант представил как то, что она «предписывает законы природе», а редукционная склонность научного мышления «к математическому аппарату включает в себя применение принудительных санкций к миру в качестве его собственного мерила $<$...> а природа становится математическим многообразием» (Хоркхаймер, Адорно, 1997: 41, 40).

В XX в. наука, любимое дитя Нового времени, на которое возлагались огромные надежды непредвзятого и объективного взгляда на мир, стала сверхмощным орудием разрушения природы и «атомной бомбой» для будущего человечества. Цинические эксперименты над людьми в концлагерях, взрывы атомных бомб в Хиросиме и Нагасаки, закрытые эксперименты по клонированию человека и другие «достижения» современной науки выводят ее из сферы объективного изучения природы в ницшеанское пространство «по ту сторону добра и зла». Фактически современная наука пошла по пути тестирования «первой природы» научными методами с помощью «приборов-протезов» ${ }^{2}$ с целью замены ее «второй природой". Героиня романа Э. Золя «Аоктор Паскаль» отмечает: «...наука все вымела подчистую, земля оголена, небо пусто <...>. Исследования и анализ вызвали крах - рухнула древняя цивилизация. И гонимое бурей, обезумевшее человечество мечется среди развалин, не зная, где преклонить голову, оно требует прочного и надежного приюта, чтобы можно было начать новую жизнь» (Золя, 1983: 353). Циническое и недружественное воздействие науки на природный мир порождает беспрецедентное за 400-летнюю историю недоверие к ней обычных людей. Претендовавшая во времена Ньютона на прочтение божественной Книги Природы ${ }^{3}$ и прошедшая этап инквизиции наука в настоящее время предстает скорее природоубийцей.

Если рассматривать в целом, циническая установка в духовной сфере является следствием того, что духовное потребление приобрело очертания «культурного 
капитализла» (Аж. Рифкин), «сделавшего товаром различные культуры, исторические эпохи, стили жизни, образы событий, явлений, персонажей, а также пропаганду, рекламу, образование, массовую культуру и массовые акции. Культура превращается в продукт массового потребления» (Макаревич, Карпухин, 2016: 141), которое уничтожает ее духовную составляющую.

Экономическая сфера. Сфера денег и торговли во все времена была материальной предпосылкой цинизма. Еще Моисей пытался уберечь свой народ от поклонения Мамоне. Но уже в Риме император Веспасиан (І в. н. э.) провозгласил, что «деньги не пахнут», а капитализм впервые открыто признал, что деньги являются не только эквивалентом обмена, но полностью определяют все стороны жизни человека. Понимание того, что существует всеобщая зависимость от безличной логики капитала, открыто Просвещением, которое строило свои прогнозы в отношении зарождающегося буржуазного общества. «Главный факт Нового времени состоит не в том, что Земля вращается вокруг Солнца, а в том, что деньги циркулируют вокруг Земли» (Слотердайк, 2007: 863). Хотя классическая экономика утверждала, что капиталистический рынок имеет стихийный характер, в глобальном обществе все меняется. Как выяснилось к концу ХХ в., и логика капитала не так уж безлична: не «невидимая рука» рынка управляет западной экономикой, «фактически и рынком, и экономикой, и государством, и обществом в целом уже управляет вполне видимая, хотя и прячущаяся рука сверхэкономики-сверхгосударства, исполнительным органом которой является денежный механизм» (Зиновьев, 2007: 485).

Экономическое развитие капитализма способствовало рождению глобальной власти, которая аккумулирует в себе не только собственно систему власти, но и высший контроль над всеми аспектами общества. Зиновьев называет эту высшую власть сверхвластью, имея в виду, что она возвышается над видимой, легитимной властью. Цинизм современной әкономической ситуации заключается в том, что государственная власть, которая больше не обладает ни суверенитетом, ни силой, делает вид, что она принимает решения, а сверхвласть не афиширует себя, но делает все государства планеты своими марионетками.

Экономическая глобализация была подготовительным этапом для глобальных процессов в других сферах. «Глобализируется прежде всего рынок, все разнообразие обменов и товаров, непрерывный денежный оборот» (Бодрийяр, 2016а: 155). Экономическую глобализацию Ж. Бодрийяр называет «промискуитетом всех знаков и всех ценностей, то есть порнографией» (там же). Он прав в том смысле, что деньги превратили человека в торгующего собой. Сформировавшийся денежный тоталитаризм заключается в том, что «из формы (средства) социальных отношений людей деньги превратились в самодовлеющую сущность, сделав людей средством для своего бытия» (там же: 111). «"Продаваемости” смыслов в условиях глобализации, когда границ для товаров, денег и идей не существует, способствует то, что нация рассматривается как бренд, а государство - как корпорация, управляющая этим брендом» (Макаревич, Карпухин, 2016: 180). Каждый народ «припечатывается » своим брендом: один - брендом сырьевой державы (как Россия), другой брендом промышленной супердержавы (как США). Поскольку «управление национальными брендами» происходит из одного центра, «брендовое клеймо» корректирует современную идентичность нации и «ставит ее на место»в глобальном распределении власти. 
В России процесс вхождения в систему сверхвласти начался после разрушения СССР и протекает на наших глазах: мы наблюдаем быструю «видовую» эволюцию - переход от политически-тоталитарного вида Homo soveticus в денежно-тоталитарный - Hoто economicus. Правильнее назвать этот переход инволюционным, потому что негативные тенденции усиливаются: цинизму советской номенклатуры можно было противостоять, потому что он проявлялся как явное идеологическое давление, от экономического диффузного цинизма защиты нет, потому что он выставил на продажу все - культурные ценности, социальные отношения и т. п.

Технологическая сфера. Научные и технические инновации «способны на противоположное» (что понимал еще Аристотель): их достижения можно использовать как во благо, так и во зло, так как они не обладают «встроенной тормозной системой» (Ж. Бодрийяр). Цинизм технологического мира заключается в обещании все большей свободы - от ручного труда, информационной перегрузки и т. п. На самом деле рост технических возможностей парадоксальным образом не раскрепощает, а сковывает человека все сильнее и сильнее: он снова становится рабом, но не другого человека, а техники. Если древний «анимизм одушевил вещь», то современный «индустриализм овеществляет души» (Хоркхаймер, Адорно, 1997: 43). Процесс овеществления усиливается, когда индустрия становится виртуальной, т. е. через образы вплотную подходит к душе человека. «Виртуальное пространство глобального - это пространство экрана, сетей, имманентности, цифрового формата безразмерное пространство-время. $<\ldots .>$ дает дорогу другому виду насилия - насилию глобального: верховенству одной лишь позитивности и технической эффективности, всесторонней организации, интегральной циркуляции, эквивалентности всех обменов» (Бодрийяр, 2016а: 157-158).

Виртуальное и сетевое насилие не очевидны, их трудно распознать, они диффузны, анонимны, легко маскируются под любые формы человеческих коммуникаций, но являются подменой. Создаются сетевые структуры - денег, информации, технологий, и у этой структуры есть хозяева и будут изгои - большинство населения

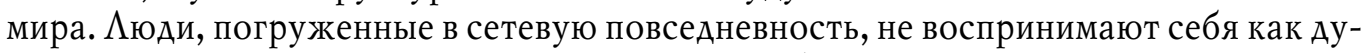
ховных деятелей и становятся социальными «роботами», их коммуникация превращается в псевдокоммуникацию, а сетевая повседневность становится симулякром традиционной повседневности.

Появление глобальных систем передачи информации создает вокруг Земли информационные пояса и служит еще одним источником глобализации. Информационная сфера является одновременно и результатом внедрения высоких технологий, и новым способом передачи знаний и информации. Информационные сети втягивают каждого жителя планеты в свою паутину и управляют им с помощью СМИ «невидимой рукой», сверхвластью, подающей сигналы к их согласованной деятельности по широкому кругу проблем. Информационная сфера, управляемая СМИ, это «третья сила» западнизма после экономики и государства. «Медиа - это могущественный инструмент формирования сознания, чувств и вкусов огромных масс людей и инструмент воздействия на них в желаемом для кого-то духе» (Зиновьев, 2007: 489-490).

Еще недавно информационная сфера была заполнена идеологическим контентом, конечно выражавшим чьи-то интересы, но все же указывающим на то, что какие-то идеи истинны, а события реальны. В эпоху глобального неоколониализма 
в «сосуды» информационной системы закачивается уже не идеологическая, а циническая информационная «жидкость», ложью заполняющая все пустоты системы и создающая циническую атмосферу глобалистской культуры. Переизбыток информации делает человека нечувствительным к знанию, как бы переполняет резервуары его сознания и не дает возможности присвоить часть информации, сделав ее собственным знанием. Тотальное отсутствие духовных смыслов и целей оставляет место лишь призрачной оболочке цинизма и создает принципиальную угрозу существованию человечества.

СМИ и пиар, став еще одним инструментом контроля, дополняют теперь полицию и военную силу, хотя они практикуют более мягкие формы насилия - дезинформацию, давление на психику, отключение сознательных процедур и др. Тотальная «информационная война» используется как для искажения конкретных событий, так и для внедрения в умы ложных идеологических стереотипов. В этой войне побеждает не моральный перевес, не перевес силы, а количество вложенных финансовых средств и степень контроля за источниками информации. Холодный расчет и цинизм вместо веры в священные лозунги Просвещения.

Политическая сфера. В глобалистском обществе гегемония одной страны формирует и единственный политический центр мира, из которого управляется остальная Империя, - это США. Суверенная монополия на применение силы отныне принадлежит этому центру, а остальные страны, ставшие недогосударствами, располагаются по степени их подчиненности сверхгосударству. Цинизм глобальной политической ситуации заключается в использовании системы двойных стандартов: государство, присваивающее себе роль «демократического наставника всего человечества», «является безжалостным и беспардонным агрессором, расчищающим себе жизненное пространство за счет других стран, и в первую очередь - за счет России» (Панарин, 2006: 276). Политический цинизм ярко проступает в том, что страна, считающая себя демократической, пытается военным путем построить монархический глобальный порядок, а также в том, что США осуществляют «беспрецедентное самоосвобождение от действия международного права и договорных обязательств» (Хомский, 2007: 113).

Цель западнизации (в терминологии А. А. Зиновьева), т. е. западной стратегии установления нового мирового порядка, в том, чтобы «довести намеченные жертвы до такого состояния, чтобы они потеряли способность к самостоятельному развитию, включить их в сферу влияния Запада, причем не в роли равноправных и равномощных партнеров, а в роли сателлитов или, лучше сказать, колоний нового типа» (Зиновьев, 2007: 417). Такую стратегию называют по-разному - «гегемониальный взгляд на мир», «либеральный национализм», «имперские устремления» (Хабермас, 2008: 37). На наш взгляд, новую политику колонизации, или западнизации, как ее называет Зиновьев, точнее называть неоколониализмом, новым колониализмом с применением более тонких и неочевидных механизмов насилия (Горелов, 2014). Но суть ее остается прежней - неравноправные отношения и использование ресурсов покоренных стран. «Эксплуатация страны в интересах Запада осуществляется силами незначительной части населения колонизируемой страны, наживающейся за счет этой ее функции и имеющей высокий жизненный стандарт, сопоставимый с таковым высших слоев Запада. <..> В военном отношении она демилитаризируется настолько. что ни о каком ее сопротивлении и речи быть не может. $<. . .>$ 
Ао жалкого уровня низводится национальная культура. Место ее занимает культура, а скорее псевдокультура западнизма» (Зиновьев, 2007: 420).

Почти отлаженная система глобального всемогущества - государственного террора - запустила такой же глобальный механизм саморазрушения - терроризм групп и одиночек, потому что «неимоверное усиление могущества усиливает желание его уничтожить» (Бодрийяр, 2016а: 98). С появлением нового терроризма началось симметричное и биполярное восхождение к крайностям насилия и цинизма: «...государственный терроризм и терроризм без государства мотивируются Аруг другом» (Глюксман, 2006: 186). Хотя терроризм не является следствием столкновения цивилизаций или религиозных убеждений, но «это современная сила, которая пытается противостоять глобализму... в его системе координат - политических, экономических, технологических и прочих. Запад стал доминирующей силой, и это - унижение для других цивилизаций» (Бодрийяр, 2016b: 193). По Бодрийяру, терроризм - четвертая мировая война, причем первые две соответствовали классическому представлению о войне (следствием первой стал конец гегемонии Европы, вторая покончила с нацизмом), третья, в виде холодной войны, положила конец коммунизму. Четвертая война - это столкновение глобального порядка «с антагонистическими силами, которые рассеяны внутри самого глобализма и которые проявляются во всех современных общественных потрясениях (Бодрийяр, 2016а: 102).

Терроризм и действует по циническим законам глобализма: смерть приходит в виде события-образа, созданного СМИ (за разрушением «башен-близнецов» 11 сентября 2001 г. в прямом эфире наблюдал весь мир); он живет в рамках тех же двойных стандартов: террористы в повседневности - обычные люди (они живут в семье, учатся или работают), но однажды пробуждаются подобно бомбе замедленного действия; он использует современный военный потенциал (за исключением ядерного оружия) и высокие технологии; победа терроризма «ощущается в подспудном разветвлении и проникновении события по всей системе - не только в виде прямой экономической, политической, биржевой и финансовой рецессии... но также в рецессии системы ценностей... всего того, что составляло гордость запаАного мира и чем он пользовался, чтобы оказать влияние на весь остальной мир» (там же: 118); отныне все проявления насилия и дестабилизации действуют в пользу терроризма, сея не только страх, который человек испытывает, сталкиваясь с враждебным, но и ужас, который рождается при встрече с неведомым.

Несмотря на внешние эффекты - жертва жизнью за убеждения, - цинизм терроризма вторичен по отношению к цинизму глобализма, это метацинизм. Отражение такой позиции видим в обращении французского писателя и публициста Ф. Мюрея «Аорогие джихадисты»: «Это мы вас создали, джихадисты и террористы, и вы закончите как узники нашего подобия. Ваш радикализм - это наш радикализм, который мы вам сбагрили. Мы можем это сделать, потому что мы безразличны ко всему, даже к нашим собственным ценностям. Вы не можете убить нас, потому что мы уже мертвы. Вы думаете, что боретесь с нами, но бессознательно вы уже стали частью нас, вы уже ассимилированы. <...> Благодаря своему акту вы снова включились в глобальную игру, которую вы проклинаете» (цит. по: там же: 140). Терроризм в конечном итоге не имеет ни смысла, ни цели и не определяется своими реальными политическими и историческими последствиями, но цинизм терроризма как всеобщей глобальной войны «проникает в наши тела и нравы» (там же: 135). 
Экологическая сфера. Предельный цинизм глобального человечества проявляется именно в отношениях человека с природой. Циническая установка возникает в этом случае из двух прямо противоположных процессов. С одной стороны, в 1970-е годы обнаружена и осознана ограниченность земных ресурсов, но, с другой стороны, именно в XX в. резко возрастает воздействие человеческой деятельности на природу, что обостряет борьбу за ресурсы и одновременно усиливает отрицательные экологические последствия такого воздействия. «Капитал - это организм, который не в состоянии обеспечивать собственное существование иначе, как устремляясь за свои пределы, обескровливая окружающую среду» (Хардт, Негри, 2004: 219).

Если раньше человечество испытывало локальные и региональные экологические кризисы, которые могли привести к гибели одной цивилизации, но не препятствовали дальнейшему прогрессу человеческого рода в целом, то теперешняя экологическая ситуация чревата глобальным экологическим коллапсом, поскольку современный человек разрушает механизмы целостного функционирования биосферы в планетарном масштабе. Биосфера - воздух, вода, флора и фауна - это то последнее, чем мы, человечество, владеем сообща. Процесс, который П. Слотердайк горько назвал «самоотравлением общества массовой коммуникации» (Слотердайк, 2010: 183), ведет к экологической катастрофе.

Существует и другая сторона глобального экологического кризиса, которая обозначает социокультурные параллели экологическому развитию: закону роста видового разнообразия в природе соответствует закон роста сочиального и культурного разнообразия вида Hото sapiens. С возникновением человека неуклонно росло количество этносов и культур, каждая из которых вносила свой вклад в сокровищницу мировой культуры. Если мы по аналогии с экологией сформулируем как закон, что культурное разнообразие прямо пропорционально устойчивости культурной системы, а культурная система в целом развивается в направлении повышения ее устойчивости, то мы получим объяснение того, почему на Земле так много культур и субкультур, и количество их до недавнего времени неуклонно росло - это необходимо для общей эволюции мировой культуры и самого человека как вида.

Современная культурная динамика, как и экологические изменения, действует по принципу обратной связи: культурное упрощение отдельного представителя человечества и рождение массового человека разрушают этническое разнообразие, так как массовый человек отказывается от своей культуры. В то же время исчезновение малых этнических культур ведет к унификации и снижению разнообразия всей человеческой культуры. Культурная глобализация, в свою очередь, в цикле обратной связи упрощает культуры этносов и индивидуальные культурные уровни людей. Возникает цикл бесконечного упрощения, а в пределе - разнообразия человеческой культуры как суперсистемы. Парадокс в том, что общий объем информации растет, а культурное разнообразие теряется. «Уравнивание всех народов имеет и другое уничтожающее действие: если все люди всех культур сражаются одним и тем же оружием, конкурируют друг с другом с помощью одной и той же техники и пытаются перехитрить друг друга на одной и той же мировой бирже, то международный отбор теряет свое твориеское действие» (Иоренц, 1998: 415-416; курсив источника. $-T$. Г.). Техногенная агрессивность современной культуры втя- 
гивает все народы в воронку ускоряющейся технической цивилизации с явными признаками духовной деградации. Формирование глобального «человейника» и монокультурной системы с экологической точки зрения ведут к гомогенизации популяции, прекращению действия естественного отбора, а значит, и эволюции.

Осознание ограниченности ресурсов и перспективы скорой экологической катастрофы подтолкнули интеллектуалов к созданию стратегических моделей выживания человечества. Эколого-математическая модель «Пределы роста» (М. Медоуз и др.) обнаружила реальные и близкие по времени пределы развития современной цивилизации. Устойчивое развитие человечества (включая и экологические аспекты), основные идеи которого сформулированы на конференции в Рио-де-Жанейро в 1992 г., и усиление глобального капитализма, возглавляемого странами «золотого миллиарда» (которые потребляют 70\% всех ресурсов мира), оказались тенденциями несовместимыми. «Золотому миллиарду» нужен путь неоколониализма, тогда как большинству населения планеты - путь устойчивого развития. В условиях осознаваемой нехватки ресурсов начинается негласная «сортировка» людей по ницшеанской схеме - на сверхчеловеков и недочеловеков: одни должны иметь шанс войти в будущее, другим следует вымирать.

Если в духовной сфере цинизм является следующей стадией после идеологии, то в экологическом смысле цинизм вырастает из антропоцентризма. В эпоху Возрождения западный человек поставил себя на высшую ступень природной иерархии, на место Бога. В XX в. были забыты экофильные принципы традиционных восточных религий - индуизма, джайнизма, синтоизма (или их используют для экзотических ритуалов). В XXI в. Запад и Восток, Север и Юг живут в соответствии с западной моделью потребления. Именно в экологической сфере циническая установка глобалистской культуры «делать худшее, зная лучшее» (имеются в виду решения конференции Рио - 92) выступает в самой обнаженной форме.

Социальная сфера. Концепция «устойчивого развития» (Рио-1992), созданная применительно к системе «человек - природа», справедлива и для системы «человек - общество». Общечеловеческий прогресс - это не только конкуренция обществ, но и эволюционное движение целого, поэтому все его составные части должны участвовать в процессе развития. Общества, как и экосистемы, могут развиваться в двух противоположных направлениях - эволюционно или инволюционно. Показателями эволюции являются качественное усложнение систем, увеличение их разнообразия и устойчивости. Показатели инволюции - упрощение систем, уменьшение их разнообразия, деградация. Эволюция ведет к развитию природы, человека и общества. Инволюция - к распаду и гибели. Как в биологической эволюции сохраняются реликтовые виды, так и в социальной существуют примеры «застывших» (аборигенных) обществ, но целостный прогресс все же зависит от обществ-лидеров.

Соответствие типа общества эволюционным тенденциям определяет место данного народа на глобальной шкале. Технологические преимущества делают западную цивилизацию лидером в глобальной конкуренции. Причина ее лидерства в максимальном соответствии народонаселения, общественного уклада и способа хозяйствования типу построенного общества. Чтобы стать эволюционно конкурентными, другие народы, используя свои преимущества, также должны строить наиболее соответствующие их духу общественные типы. Осознание необходимос- 
ти гармонии трех отмеченных компонентов - народонаселения, соответствия способа жизни типу общества и стремления соответствовать мировым тенденциям позволяет некоторым странам, таким как Китай, Индия и некоторые страны ЮгоВосточной Азии, подбираться к Западу в эволюционной социальной гонке. Их борьба с Западом может стать доминантой развития мира в XXI в. Но главными двигателями современной глобальной социальной системы на государственном уровне все же остаются западные страны. Несомненно, что они будут стремиться строить мир по своим правилам. Цинизм глобальной социальной ситуации в том, что современная сверхвласть - это не класс воинов, получивших свои регалии за мужество и доблесть, не класс аристократов, обладающих «генетическим» статусом на основе родословной, не класс буржуа, создавших массовое производство, и даже не сообщество государственных мужей, радеющих о будущности своего народа, а горстка удачливых и не брезгующих никакими средствами глобальных финансовых спекулянтов. Бухгалтеры пытаются навязать всему человечеству пути их дальнейшей әволюции! Парадоксально, но это им удается.

Глобализация осложняется отсутствием глобальных этических норм. Исторически правила общежития сформировались в пределах малых групп, а в отношении Аругих групп были дозволены любые формы агрессии - убийство, насилие, обращение в рабство и т. п. В результате столкновения культур и этносов глобализация актуализирует конфликт внутри- и межгрупповых этических норм. Этический конфликт особенно заметен при соприкосновении различных культур. Одним из двигателей глобальной социальной системы являются мигранты - люди, оторвавшиеся от своей родины и перемещенные в чуждую им культуру. Последствиями миграции в психологическом смысле являются, с одной стороны, недеятельное состояние, меланхолия, которая «представляет собой в чистом виде патологию эмиграции - оскудение внутреннего мира в результате потери жизнетворного поля близости» (Хоркхаймер, Адорно, 1997: 475). Часто, пытаясь закрепиться в чуждом мире, мигранты не эмансипируюся, а, напротив, создают сообщества, подобные тем, что были на родине, - с теми же традициями, культурой, религией. Крах практики мультикультурализма, о котором заявили европейцы, свидетельствует о том, что национальная культура все еще является «домом» для большинства жителей Земли. Но, с другой стороны, появление глобального терроризма свидетельствует о том, что нарастает агрессия мигрантов против ценностей доминирующей европейской цивилизации, которая не становится родиной для большинства из них. Еще Ницше понимал, что «те же самые люди, которые inter pares (на родине. - Т. Г.) столь строго придерживаются правил... за пределами своей среды, там, где начинается чужое, чужбина, ведут себя немногим лучше выпущенных на волю хищных зверей» (цит. по: Слотердайк, 2007: 945). В целом агрессивная стратегия глобализации ставит под вопрос реальность объединения всех народов в человечество.

Можно отметить также, что человек-мигрант - это исторический типаж, соответствующий объективной эволюционной тенденции. Мигрантом был древний Homo sapiens, вышедший из Африки и заселявший по очереди все материки; в недавнем прошлом мигранты освоили оба американских материка и Австралию. Иными словами, в сосудах любого народа течет кровь мигрантов. Но каждый раз, приходя на чужую землю, перемешиваясь с местными этносами или сохраняя автономию, пришельцы создавали свою культуру, которая становилась «средой обита- 
ния» и способствовала рождению нового народа как субъекта истории. Теперь глобализация выбрасывает и города, и сельские поселения в гомогенизирующее коммуникативное пространство. Пойманные в него, как в сети, они утрачивают издревле присущую им привилегию быть для самих себя центром мира. В такой ситуации цинизм как центризация личности становится подменой патриотизма как духовной связи с родной средой. О том, что весь мир пришел в движение, свидетельствует также глобальный рост туризма. Современный «любитель новых ландшафтов», по сути, является «слепым пассажиром», заинтересованным только в том, чтобы их просто пересечь (там же: 846).

Особенность глобалистской культуры состоит в том, что она не только разрушает возможность появления новых этнических (пусть и мигрантских) культур, но и по причине своей бездуховности и цинизма препятствует становлению культуры глобальной цивилизации.

Сфера личности. Цинизм присутствует в любой культуре, поскольку имеет и онтологические, и гносеологические предпосылки для своего существования. Современный гипертрофированный цинизм, завоевавший и глобальный социум, и отдельную личность, становится болезненным и разрушительным, потому что занимает чужую познавательную территорию и вытесняет все другие способы отношения к миру. Понятно, что источник цинизма, ставшего глобальным мировоззрением, находится внутри отдельной личности, причем его тоталитарность означает, что таких личностей большинство.

В лексиконе повседневности существует понятие «здоровый цинизм», имеющее некий позитивный оттенок и предполагающее интеллектуальную позицию человека, способного отстраненно и иронично взглянуть на реальность. Считается, что такой взгляд на мир защищает от экзистенциальной фрустрации, социального вакуума, разочарования и апатии. Человек по своей природе - открытая система: в материальном смысле это выражается (как и у других живых существ) в потреблении вещества и энергии. В духовном смысле он тоже открыт, так как извне получает информацию и духовную энергию. Цинизм, позиционирующий себя как защитную оболочку от неблагоприятных внешних воздействий - социальных, психологических и др., на самом деле ведет к әгоцентрическому замыканию на себя и агрессии (так как человек как бы борется с внешней угрозой, которой на самом деле не существует), а неоткрытость миру - к регрессивным духовным и моральным тенденциям - расщепленности и обеднению личности (Горелова, 2017).

Распад ядра личности проявляется как невротическая расщепленность - неспособность человека реагировать на свои внутренние конфликты, делать осознанный выбор и брать за него ответственность. Последствия неразрешимых внутренних конфликтов хорошо исследованы психоанализом. Это и нагромождение страхов, провоцирующее отчуждение человека от мира и самого себя. Это также обеднение личности: «Когда человек в своей основе разделен на части, он никогда не может целиком отдать свои силы чему-либо» (Хорни, 1995: 115). «Энергетическое обеднение» личности, по Хорни, проявляется как невротическая инерция, парализующая инициативу деятельности. Психологическое расщепление ведет к расщеплению «в вопросах морального характера, то есть в моральных принципах и всех чувствах, отношениях и формах поведения, которые затрагивают связи человека с другими людьми. <..> Характерными чертами разрушения нравственной цель- 
ности являются уменьшение искренности и возрастание эгоцентризма» (там же: 120, 121).

Сопутствующими проявлениями цинизма становятся как беспредельное лищемерие: притворная любовь, притворная доброта, притворная тяга к знаниям, притворная честность пронизывают все сферы жизни от семьи и школы до бизнеса и политики, так и нигилизм: отрицание общества, культуры и даже самоотрицание (что присуще, например, терроризму). Степени самоотрицания располагаются по нарастающей шкале от недовольства телом и лицом (на нем держится косметологическая индустрия) через применение в широких масштабах «протезов и клонов» (о чем писал Ж. Бодрийяр) до полного отрицания человеческой сущности в попытках создания роботов и киборгов.

Современный циник - это разочаровавшийся в жизни человек, перешагнувший линию добра и зла из-за отсутствия смысла жизни и системы ценностей. Циники как бы представляют собой особый тип атеиста: они не только не верят в Бога или в то, что им говорят, но вообще не способны верить во что-либо. В глубине личности воцаряется хаос, и «...каждый оказывается другой и никто не он сам» (Хайдеггер, 1997: 128). А человечество в целом превращается в «гигантского обитателя мира, платящего цену за символическую и материальную комфортность своей формы жизни, заключающуюся в том, что он позволяет вовлечь себя в поток всеобщего опустошения внутреннего мира» (Слотердайк, 2005: 684)

Рациональность современного человека оказывается зажатой между прислушиванием к изощренному доносительству «любимого Я» и самореализацией как формой проявления эгоизма. Закрытый индивидуализм рождает «страх перед свободой» (Э. Фромм) и нежелание рискнуть своей жизнью, чтобы строить духовную творческую индивидуальность. Таким образом, рациональное освобождение разума, о котором мечтала западная культура, в конечном счете привело к его «схлопыванию» - бесплодности и цинизму.

\section{ЗАКАЮЧЕНИЕ}

Идеология, которая в XX в. была доминирующей отраслью культуры, в XXI в. сменяется цинизмом, имеющим более сложную структуру. Как следует из определения и по происхождению, цинизм является не только мировоззрением, из которого следуют определенные жизненные установки, но он также нацелен (даже как бы требует) на практическое осуществление этих установок. В современной глобальной культуре он не только заполняет лакуны и пустоты исчезающей духовной системы культуры, но вызывает определенные формы поведения людей, т. е. фактически становится глобальным способом жизни общества и культуры.

В эволюционном плане циническая установка проходит путь от первоначальной позитивной фазы кинизма, который призывает к отказу от ценностей массовой культуры для индивидуального поиска высших универсальных (космических) ценностей, к современной фазе, на которой утверждается отказ от высших ценностей в пользу ценностей массовой (и одновременно глобалистской) культуры. Одиночка и яркий индивидуалист Аиоген, живший в маленьком полисе, пришел к пониманию, что он - «гражданин мира», тогда как современный обитатель глобального человейника, которому доступна любая точка планеты, теряя духовную индивидуальность, пытается «засветиться» (на ТВ, в соцсетях и т. п.) с помощью внешних при- 
емов - эпатажа и даже преступлений. Произошла подмена, и личность больше не жаждет духовного универсума, а приходящий взамен двойник имеет примитивный облик потребления и соблазна.

Безысходность цинической стадии глобалистской культуры возникает в результате взаимного влияния и обратной связи трех компонентов, которые усиливают общую тенденцию, - цинических установок, цинического способа существования общества и общей атмосферы цинизма. Такую атмосферу сотворили «новые хозяева мирового интеллекта», как о них пишет А. А. Зиновьев, которые овладели им и действуют в русле, соответствующем их интересам и силе. Поэтому «...интеллектуальная среда загрязнена, отравлена, изуродована еще больше, чем среда природная. И это не вызывает никакой тревоги ни у кого, вообще не замечается и не воспринимается как явление катастрофическое» (Зиновьев, 2006: 511).

Аля некоторых западных мыслителей сценарий будущего развития цивилизации выглядит оптимистично. «Если поначалу покажется, что Просвещение неизбежно заканчивается циническим разочарованием, то вскоре лист будет перевернут, и исследование цинизма станет обоснованием славной свободы от иллюзий. Просвещение всегда было разочарованием - в позитивном смысле слова, разочарованием как освобождением от чар, и чем больше оно прогрессирует, тем ближе момент, когда разум заставит нас сделать попытку утверждения чего-либо» (Слотердайк, 2009: 24). Современная циническая стадия предстает лишь как период относительного застоя в момент, когда на смену политической глобализации приходит глобализация медиатехнологическая. По Слотердайку, выход за пределы метафизической интерпретации человека открывает возможность использования биотехнологий и радикального телесного преображения человечества.

Но дело в том, что цинизм и как мировоззрение, и как способ действия как бы внутренне замкнут на себя и не формирует вектор развития. Сам же Слотердайк отмечает, что циническое существование создает контур обратной связи внутри самозамкнутой системы: цинический разум способствует постоянному упражнению в недоверии, стремясь превзойти обман и постоянно испытывая подозрение. Второй стороной цинизма является его способность «изготовлять» систему самоподавления человека, действующую глобально, но нацеленную на группы и отдельных индивидов. Такое циническое воздействие имеет вирусный характер: оно осуществляется через заражение, развивается как болезнь и постепенно разрушает и духовный иммунитет, и социальную способность к сопротивлению. В атмосфере цинизма становятся не нужными духовные системы, в том числе и идеология, которая если и нужна, то лишь как внешняя настройка, как вирус, который заражает.

Ответ на Вызов (в терминологии концепции А. Тойнби) цинизма видится нам в соииально-духовном преображении человека. Это не одномоментный процесс, вероятно, он имеет несколько фаз. Во-первых, человек должен осознать, так сказать, уровень своего цинизма, признать его своей проблемой и пытаться найти выход. Во-вторых, говоря чеховским языком, выдавливание по капле из себя циника - это действие, которое включает не только повседневную практику и разумные установки, но и веру в широком смысле слова - в Бога, смысл жизни, целесообразное буАущее, в себя. В-третьих, антицинические практики одиночек ведут к замкнутости и социальной аномии. Поэтому такие практики должны стать социальными, т. е. они предполагают воспитание и наличие воспитателей. Аля изменения системы 
воспитания нужно, чтобы общество осознало смыслы и ценности и изменило цели развития. Когда идеалом общественного развития станет человек-творец, личность, нацеленная на духовный поиск, тогда будут востребованы в полной мере все те наработки, которые вошли в золотой фонд общечеловеческой культуры. Таким образом, выход из поля цинизма и духовное выздоровление человечества требуют индивидуальных, социальных и культурных усилий каждого жителя Земли.

\section{ПРИМЕЧАНИЯ}

1 Римские последователи кинизма сильно отличались от греческих. «Смеховой мотив, вызванный к жизни афинским кинизмом, погиб в кинизме позднеримском. Секта объединяла скорее людей слабых, полных неприязни и зависти, прихлебателей, попрошаек и бродяг, ханжей, изгоев и типов, склонных к нарциссизму и позерству, чем насмешливых индивидуалистов» (Слотердайк, 2009: 271). Соответствующее отношение к ним римских граждан придавало негативное наполнение практике кинизма (в латинской транскрипции - цинизма).

2 В понимании Ж. Бодрийяра приборы являются продолжением органов чувств и рук человека и в этом смысле становятся протезами.

3 Наука Нового времени имела в виду существование двух типов знания - Библии как книги Бога и научного знания как книги Природы.

\section{СПИСОК АИТЕРАТУРЫ}

Бжезинский, 3. (2012) Стратегический взгляд: Америка и глобальный кризис / пер. с англ. М. Аесятовой. М. : Астрель. 285 с.

Блог-платформа «Цинизм как образ жизни» [Электронный ресурс] // Vision. URL: https:// yvision.kz/post/58465ep (дата обращения: 05.07.2017).

Бодрийяр, Ж. (2012) Прозрачность зла / пер. с фр. А. Аюбарской, Е. Марковской. М. : Аобросвет ; Изд-во «КАУ». 260 с.

Бодрийяр, Ж. (2016а) Аух терроризма // Бодрийяр, Ж. Аух терроризма. Войны в заливе не было / пер. с фр. А. Качалова. М. : РИПОА классик. 224 с. С. 95-188.

Бодрийяр, Ж. (2016b) Меланхолический Ницше // Бодрийяр Ж. Аух терроризма. Войны в заливе не было / пер. с фр. А. Качалова. М. : РИПО А классик. 224 с. С. 189-204.

Вейдле, В. В. (2011) Задача России. Минск : Белорусская православная церковь. 512 с.

Глюксман, А. (2006) Аостоевский на Манхеттене / пер. с фр. В. Бабинцева. Екатеринбург : У-Фактория. 224 с.

Горелов, А. А. (2014) Глобальный неоколониализм и русская идея. М. : $\Lambda$ ЕНАНА. 256 с.

Горелова, Т. А. (2017) Пределы парадигмы индивидуальности // Знание. Понимание. Умение. № 2. C. 56-70. DOI: 10.17805/zpu.2017.2.4

Жижек, С. (1999) Возвышенный объект идеологии. М. : Художественный журнал. 238 с.

Зиновьев, А. А. (2006) Фактор понимания. М. : Алгоритм ; Эксмо. 528 с.

Зиновьев, А. А. (2007) Запад. М. : Алгоритм ; Эксмо. 512 с.

Золя, Э. (1983) Страница любви. Аоктор Паскаль. М. : Правда. 576 с.

Кант, И. (1966) Ответ на вопрос: что такое просвещение // Кант, И. Сочинения : в 6 т. М. : Мысль. Т. 6. 743 с. С. 25-36.

Карелин, Р. Н. (1999) Церковь и мир на пороге апокалипсиса. М. : Московское Подворье Свято-Троицкой Сергиевой Аавры. 265 с.

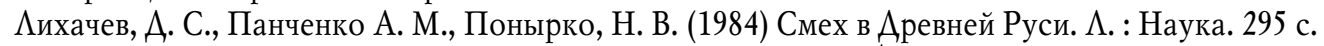

Аоренц, К. (1998) Оборотная сторона зеркала : пер. с нем. / под ред. А. В. Гладкого; сост. А. В. Гладкого, А. И. Федорова ; послесловие А. И. Федорова. М. : Республика. 393 с.

Макаревич, Э. Ф., Карпухин О. И. (2016) Блеск и нищета массовых коммуникаций. М. : Издво АНО «Парламентская газета». 398 с.

Панарин, А. С. (2001) Политология. М. : Изд-во МГУ. 346 с.

Панарин, А. С. (2006) Народ без элиты. М. : Алгоритм. 352 с. 

$124 \mathrm{c}$

Петров, К. А. (2015) Постметафизическая философия Петера Слотердайка. М. : Русайнс.

Словарь русского языка (1952) / сост. С. И. Ожегов. М. : Гос. изд-во иностранных и нац. языков. 848 с.

Слотердайк, П. (2005) Сферы. Микросферология : в 3 т. / пер. с нем. К. В. Аощевского. СПб. : Наука. Т. 1. Пузыри. 690 с.

Слотердайк, П. (2007) Сферы. Макросферология : в 3 т. / пер. с нем. К. В. Аощевского. СПб. : Наука. Т. 2. Глобусы. 1026 с.

Слотердайк, П. (2009) Критика цинического разума / пер. с нем. А. П. Перцева. Екатеринбург : У-Фактория ; М. : АСТ. 800 с.

Слотердайк, П. (2010) Сферы. Плюральная сферология : в 3 т. / пер. с нем. К. В. Аощевского. СПб. : Наука. Т. 3. Пена. 925 с.

Хабермас, Ю. (2008) Расколотый Запад/ пер. с нем. О. М. Величко, Е. А. Петренко. М. : Весь мир. 192 с.

Хайдеггер, М. (1997) Бытие и время. М. : Ad Marginem. 452 с.

Хардт, М., Негри А. (2004) Империя / пер. с англ., под ред. Г. В. Каменской, М. С. Фетисова. М. : Праксис. 440 с.

Хомский, Н. (2007) Несостоятельные Штаты: злоупотребление властью и атака на демократию / пер. с англ. В. Панова. М. : Столица-Принт. 480 с.

Хоркхаймер, М., Адорно, Т. В. (1997) Аиалектика Просвещения. Философские фрагменты / пер. с нем. М. Кузнецова. М. ; СПб. : Медиум ; Ювента. 312 с.

Хорни, К. (1995) Наши внутренние конфликты // Психоанализ и культура. Избранные труды Карен Хорни и Эриха Фромма. М. : Юрист. 623 с. С. 7-190. $527 \mathrm{c.}$

Ясперс, К. (1994) Смысл и назначение истории / пер. с нем. М. И. Аевиной. М. : Республика.

Аата поступления: 12.12.2017 2.

\section{CYNICISM AS A WAY OF EXISTENCE OF GLOBALIST CULTURE \\ T. A. GORELOVA \\ MOSCOW UNIVERSITY FOR THE HUMANITIES}

The article examines the role of the cynical worldview in contemporary culture, which the author called globalist (a concept derived from "globalism" in A. A. Zinoviev's interpretation). Special features of this culture are manifested as the absence of a national core; mass character; "viral" mode of distribution; and the striving to destroy the system of traditional values. Cynical worldview becomes the core of this culture, penetrating all spheres of modern life and acting not only as a worldview, but also as a way of existence of mankind.

According to P. Sloterdijk, the historical path of cynicism can be represented as a form of expansion of false attitudes and stereotypes, both in the individual and in the public consciousness: Lies $\rightarrow$ Misconception $\rightarrow$ Ideology $\rightarrow$ Cynicism. The latter appears as the next stage of social and cultural evolution following ideology, as the postmodern worldview. Life in large cities and the informatisation of consciousness contribute to the fact that the nature of cynicism becomes viral, and cynicism itself becomes diffuse because of this nature. The work shows that in the spiritual sphere cynicism becomes a substitute for spiritual development in all branches of culture.

The cynicism of the current economic situation lies, at the social level, in the fact that the state power no longer has sovereignty, and decisions are made, in fact, by the global superpower; at the level of individual, money, having become a self-sufficient entity, has made everyone a means of one's being. The cynicism of the global social situation is that modern superpower is not a stratum of soldiers who have received their regalia for courage and valor, not a stratum of aristocrats possessing a "genetic" status on the basis of genealogy, not a bourgeois stratum that created mass production, and not even a community of statesmen who care about the future of their people, but a handful of fortunate global financial speculators who are not squeamish by any means. 
The cynicism of the technological world lies in the promise of ever greater freedom, but in reality a person remains a slave, although not to another person, but to technology. The cynicism of the global political situation is in the creation of a system of global neocolonialism and the use of double standards: a state that assumes the role of a democratic mentor of mankind is a ruthless aggressor clearing its living space at the expense of other countries, while state terrorism and terrorism against the state are motivated by each other. The information sphere, managed by the media, creates a "circulatory" system of globalist culture, into which not ideological but cynical informational "fluid» is now being injected. The ultimate cynicism of the global humankind - "doing the worst, knowing the best" - is especially evident in the environmental sphere: on the one hand, the limited resources of the earth are acknowledged, but on the other hand, the impact of human activity on nature is increasing sharply, which escalates the struggle for resources and, at the same time, intensifies the negative environmental consequences of such an impact.

Keywords: cynicism; globalism; globalist culture; ideology; individuality; evolution

\section{REFERENCES}

Bzhezinskii, Z. (2012) Strategicheskii vzgliad: Amerika i global'nyi krizis / transl. from Engl. Moscow, Astrel'. 285 p. (In Russ.).

Blog-platforma "Tsinizm kak obraz zhizni". Vision [online] Available at: https://yvision.kz/ post/58465er (access date: 05.07.2017). (In Russ.).

Bodriiiar, Zh. (2012) Prozrachnost' zla / transl. from Fr. Moscow, Dobrosvet; Izd-vo "KDU". 260 p. (In Russ.).

Bodriiiar, Zh. (2016a) Dukh terrorizma. In: Bodriiiar, Zh. Dukb terrorizma. Voiny $v$ zalive ne bylo / transl. from Fr. Moscow, RIPOL klassik. 224 p. Pp. 95-188. (In Russ.).

Bodriiiar, Zh. (2016b) Melankholicheskii Nitsshe. In: Bodriiiar Zh. Dukb terrorizma. Voiny v zalive ne bylo / transl. from Fr. Moscow, RIPOL klassik. 224 p. Pp. 189-204. (In Russ.).

Veidle, V. V. (2011) Zadacha Rossii. Minsk, Belorusskaia pravoslavnaia tserkov'. 512 p. (In Russ.).

Gliuksman, A. (2006) Dostoevskii na Mankbettene / transl. from Fr. Ekaterinburg, U-Faktoriia. 224 p. (In Russ.).

Gorelov, A. A. (2014) Global'nyi neokolonializm i russkaia ideia. Moscow, LENAND. 256 p. (In Russ.).

Gorelova, T. A. (2017) Predely paradigmy individual'nosti. Znanie. Ponimanie. Umenie, no. 2, pp. 56-70. DOI: 10.17805/zpu.2017.2.4 (In Russ.).

Zhizhek, S. (1999) Vozvyshennyi ob'ekt ideologii. Moscow, Khudozhestvennyi zhurnal. 238 p. (In Russ.).

Zinov'ev, A. A. (2006) Faktor ponimaniia. Moscow, Algoritm, Eksmo. 528 p. (In Russ.).

Zinov'ev, A. A. (2007) Zapad. Moscow, Algoritm, Eksmo. 512 p. (In Russ.).

Zolia, E. (1983) Stranitsa liubvi. Doktor Paskal'. Moscow, Pravda. 576 p. (In Russ.).

Kant, I. (1966) Otvet na vopros: chto takoe prosveshchenie. In: Kant, I. Sochineniia : in 6 vol. Moscow, Mysl'. Vol. 6. 743 p. Pp. 25-36. (In Russ.).

Karelin, R. N. (1999) Tserkov' i mir na poroge apokalipsisa. Moscow, Moskovskoe Podvor'e Sviato-Troitskoi Sergievoi Lavry. 265 p. (In Russ.).

Likhachev, D. S., Panchenko A. M. and Ponyrko, N. V. (1984) Smekb v Drevnei Rusi. Leningrad, Nauka. 295 p. (In Russ.).

Lorents, K. (1998) Oborotnaia storona zerkala: transl. from Germ./ ed. by A. V. Gladkogo; comp. by A. V. Gladkogo and A. I. Fedorova. Moscow, Respublika. 393 p. (In Russ.).

Makarevich, E. F. and Karpukhin O. I. (2016) Blesk i nishcheta massovykb kommunikatsii. Moscow, Izd-vo ANO "Parlamentskaia gazeta". 398 p. (In Russ.).

Panarin, A. S. (2001) Politologiia. Moscow, Izd-vo MGU. 346 p. (In Russ.).

Panarin, A. S. (2006) Narod bez elity. Moscow, Algoritm. 352 p. (In Russ.).

Petrov, K. A. (2015) Postmetafizicheskaia filosofiia Petera Sloterdaika. Moscow, Rusains. 124 p. (In Russ.). 
Slovar' russkogo iazyka (1952) / comp. by S. I. Ozhegov. Moscow, Gos. izd-vo inostrannykh i nats. iazykov. 848 p. (In Russ.).

Sloterdaik, P. (2005) Sfery. Mikrosferologiia : in 3 vol./ transl. from Germ. by K. V. Loshchevskii. St. Petersburg, Nauka. Vol. 1. Puzyri. 690 p. (In Russ.).

Sloterdaik, P. (2007) Sfery. Makrosferologiia: in 3 vol. / transl. from Germ. by K. V. Loshchevskii. St. Petersburg, Nauka. Vol. 2. Globusy. 1026 p. (In Russ.).

Sloterdaik, P. (2009) Kritika tsinicheskogo razuma / transl. from Germ. by A. P. Pertsev. Ekaterinburg, U-Faktoriia; Moscow, AST. 800 p. (In Russ.).

Sloterdaik, P. (2010) Sfery. Pliural'naia sferologiia: in 3 vol. / transl. from Germ. by K. V. Loshchevskii. St. Petersburg, Nauka. Vol. 3. Pena. 925 p.

Khabermas, Iu. (2008) Raskolotyi Zapad / transl. from Germ. by O. M. Velichko and E. L. Petrenko. Moscow, Ves' mir. 192 p. (In Russ.).

Khaidegger, M. (1997) Bytie i vremia. Moscow, Ad Marginem. 452 p. (In Russ.).

Khardt, M. and Negri A. (2004) Imperiia / transl. from Engl. Moscow, Praksis. 440 p. (In Russ.).

Khomskii, N. (2007) Nesostoiatel'nye Shtaty: zloupotreblenie vlast'iu i ataka na demokratiiu / transl. from Engl. by V. Panov. Moscow, Stolitsa-Print. 480 p. (In Russ.).

Khorkkhaimer, M. and Adorno, T. V. (1997) Dialektika Prosveshcheniia. Filosofskie fragmenty / transl. from Germ. by M. Kuznetsova. Moscow, St. Petersburg, Medium, Iuventa. 312 p. (In Russ.).

Khorni, K. (1995) Nashi vnutrennie konflikty. In: Psikboanaliz i kul'tura. Izbrannye trudy Karen Khorni i Erikba Fromma. Moscow, Iurist. 623 p. Pp. 7-190. (In Russ.).

Iaspers, K. (1994) Smysl $i$ naznachenie istorii / transl. from Germ. by M. I. Levina. Moscow, Respublika. 527 p. (In Russ.).

Submission date: 12.12 .2017$.

Горелова Татьяна Анатольевна - доктор философских наук, профессор кафедры философии, культурологии и политологии Московского гуманитарного университета. Адрес: 111395, Россия, г. Москва, ул. Юности, д. 5. Тел.: +7 (499) 374-55-11. Эл. адрес: fylosofy@mosgu.ru

Gorelova Tatyana Anatolievna, Doctor of Philosophy, Professor, Department of Philosophy, Culturology and Politology, Moscow University for the Humanities. Postal address: 5, Yunosti St., Moscow, Russian Federation, 111395. Tel.: +7 (499) 374-55-11. E-mail: fylosofy@mosgu.ru 